\title{
Increasing Family Awareness of COVID-19 Transmission In Vulnerable Communities
}

\author{
Iche Andriyani Liberty ${ }^{1 *}$, Muhammad Zainal Fikri ${ }^{2}$, Tri Hari Irfani ${ }^{1}$, Pariyana ${ }^{1}$, Suryadi \\ Tjekyan $^{1}$ \\ ${ }^{1}$ Departmen of Public Health and Community Medicine, Medical Faculty, \\ University of Sriwijaya, South Sumatera, Indonesia \\ ${ }^{2}$ Psychology Study Program, Medical Faculty, \\ University of Sriwijaya, South Sumatera, Indonesia \\ * Corresponding Author: \\ Email: iche.aliberty@gmail.com
}

\begin{abstract}
.
COVID-19 cases in Indonesia are still quite high. However, community mobility continues to increase. If in a family there is a vulnerable and / or comorbid age group, it will certainly be increasingly threatened when a productive family member leaves the house but is negligent in implementing health protocols. People who live in market areas, of course, are in direct contact with high economic activities and of course also indicate high mobility. The purpose of this activity is to increase family awareness of COVID-19 transmission in vulnerable communities with comorbidities. The target audience for this community service activity is 31 people who live in the Jakabaring Main Market area of Palembang City. This community service activity results in an increase in knowledge about the importance of health protocols that are carried out in a disciplined and correct manner. This health protocol is carried out in order to protect each other starting from the family and for the community, especially for vulnerable communities. Apart from home visiting activities, the construction of hand washing facilities will also be used by the surrounding community and at the same time become a symbol to remind that washing hands with soap in running water is not only an obligation of the health protocol for preventing COVID-19 but will also save many lives from various threats of other infectious diseases.
\end{abstract}

Keywords: vigilance, COVID-19, vulnerable communities

\section{INTRODUCTION}

The corona epidemic (SARS-CoV 2) began to spread in December 2019 in Wuhan, China. The outbreak has caused 4291 deaths and 118,000 positive cases in 114 countries, so the WHO declared it a pandemic [1 - 5]. The SARS-CoV 2 pandemic has affected various sectors, especially health and the economy. Indonesia is currently implementing Large-Scale Social Restrictions (PSBB) in several areas which has almost paralyzed the economic sector. So far, not much is known about the COVID-19 disease and prevention cannot be carried out continuously because it will have a wider impact. For this reason, the Indonesian government makes efforts to mitigate and prepare the workplace as optimally as possible so that it can adapt through changes in lifestyle in Indonesia. This situation is called the new normal (Adaptation of New Life) [6].The new normal (new normal) is a term that results from the adaptation process during the COVID-19 pandemic. Humans will have new habits from the learning https://ijcsnet.id 
process and adaptation process after the COVID-19 pandemic [2]. Since the emergence of the discourse on implementing the new normal, various pros and cons have arisen among the community. Indonesia is considered not ready to relax PSBB and implement the new normal because among the influencing factors are the health system that is not ready and preventive behavior has not been carried out effectively [7].

On the other hand, Indonesia is starting to prepare for a new normal discourse while positive cases of COVID-19 have not decreased. Even so, the COVID-19 task force which reported several green zones also did not recommend the new normal due to the high number of infection cases. According to Monoarfa, the implementation of the new normal requires residents to wear masks outside their homes, bring hand sanitizer and wash their hands with soap, besides that physical distancing will also be applied. Work as much as possible is done from home, limiting the number of people in the workplace. The central government is also planning to implement sick leave and public campaigns for health protocols in public places such as airports, schools, cinemas and sports facilities.Based on data from the Indonesian Ministry of Health, as of September 27, 2020, COVID-19 cases in Indonesia are still quite high. The number of positive confirmed cases was 275,213 cases, 10,386 cases died (3.8\%), recovered 203,014 cases $(73.8 \%)$, and cases are still under treatment as many as 61,813 cases $(22.5 \%)$ [8]. South Sumatra is one of the provinces with a high number of confirmed cases (ranked 12th in Indonesia) and a fairly high mortality rate (of 5.79\%) [9]. Both nationally and provincially, almost $70 \%$ of the deaths were in the age group over 55 years old and with comorbidities, most of which were type 2 diabetes mellitus and hypertension.

But unfortunately, the mobility of the people of South Sumatra based on the google mobility index continues to increase, the percentage of South Sumatran people who live at home is only $12 \%$, while the mobilization with the aim of going to retail centers, recreation, parks and grocery stores continues to increase [10]. So, if in a family there is a vulnerable age group and or has comorbidities, it will certainly be increasingly threatened when productive family members leave the house but are negligent in carrying out health protocols [11].The city of Palembang which is the capital of South Sumatra Province with high social and economic activities as well as with high confirmed cases and deaths also needs to be given priority to be given a form of dedication from the Sriwijaya University academic community. People who live in market areas, of course, have direct contact with high economic activities and of course also indicate that they have high mobility. The big market in Palembang City that is still actively operating and has the potential for crowds and arrivals from people from various regions of South Sumatra is the Jakabaring Palembang Main Market which is located on Jalan Pangeran Ratu, Palembang City. So that one form of community service that can be given is through community service activities in the form of lectures / counseling which aims to increase family awareness of the transmission of COVID19 to vulnerable communities in the Jakabaring Main Market area. It is hoped that this 
service activity will be useful for the community and health service providers in making efforts to prevent COVID-19.

\section{METHODS}

The implementation of this community service activity was carried out for 3 (three) days from November 28, 2020 to November 30, 2020 in residential housing in the Jakabaring Main Market area. This Community Service activity consists of several stages, namely:Phase 1 (first day): assessing the public's knowledge of health protocols to protect vulnerable communities using a questionnaire and knowing the distribution of houses of residents who have vulnerable communities and can accept the activity. After obtaining an overview of community knowledge, then the material is compiled on which aspects need to be improved.

Phase 2 (second day): providing education / counseling about the importance of health protocols in order to protect vulnerable communities with home visits from house to house of residents who have vulnerable communities. This activity was carried out in 25 residents' houses.Phase 3 (third day): together with the community build hand washing facilities in the local prayer room area.

\section{RESULT AND DISCUSSION}

This community service activity was carried out with a total of 31 participants. Most of the participants $64.53 \%$ are over 60 years old, $74.2 \%$ are female, the majority are not working $(67.7 \%)$ and with the last education level of junior high school as many as $54.8 \%$ The following is table 1 , the characteristics of the activity participants.

Table 1. Characteristics of Participants

\begin{tabular}{|c|c|c|}
\hline Variable & Total & Percentage $(\%)$ \\
\hline \multicolumn{3}{|l|}{ Age } \\
\hline$<60$ years & 11 & 35,48 \\
\hline$>=60$ years & 20 & 64,52 \\
\hline \multicolumn{3}{|l|}{ Sex } \\
\hline Female & 23 & 74,2 \\
\hline Male & 8 & 25,8 \\
\hline \multicolumn{3}{|l|}{ Occupation } \\
\hline Labor & 10 & 32,3 \\
\hline Does not work & 21 & 67,7 \\
\hline \multicolumn{3}{|l|}{ Education Level } \\
\hline Primary School & 12 & 38,7 \\
\hline Junior High School & 17 & 54,8 \\
\hline Senior High School & 2 & 6,5 \\
\hline
\end{tabular}


Table 2. Behavior of Health Protocol Implementation

Variable

Use of masks when working outside the home

Yes

No

How to Use Mask

Cover the mouth and nose area

Change the mask every 4 hours / when it's too humid Yes

No

\section{Handwashing Behavior with Soap}

$<3$ times a day

$>=3$ times a day
Total

Percentage $(\%)$

$\begin{array}{cc}29 & 93,5 \\ 2 & 6,5 \\ 31 & 100 \\ 2 & 6,5 \\ 29 & 93,5 \\ 10 & 32,3 \\ 21 & 67,7\end{array}$

Maintain a minimum distance of 1-meter when interacting outside the house

Always

13

41,9

Sometimes

18

The description of the behavior of implementing the health protocol (wearing masks, washing hands with soap, and maintaining distance) of the 31 participants, most of them already used masks when doing activities outside the home $(93.5 \%)$ by using the correct mask, namely covering the mouth and nose $(100 \%)$, but to change the mask every 4 hours or when it is too humid, only $6.5 \%$ do it. The second health protocol, namely washing hands with soap after activities, most of the participants, namely $67.7 \%$, did it with a frequency $>=3$ times a day. Meanwhile, the behavior of maintaining a minimum distance of 1 -meter when interacting outside the home is still sometimes carried out by $58.1 \%$ of participants. The results of this preliminary survey are then used as the basis for what aspects need to be emphasized during home visits or home visits to provide counseling.
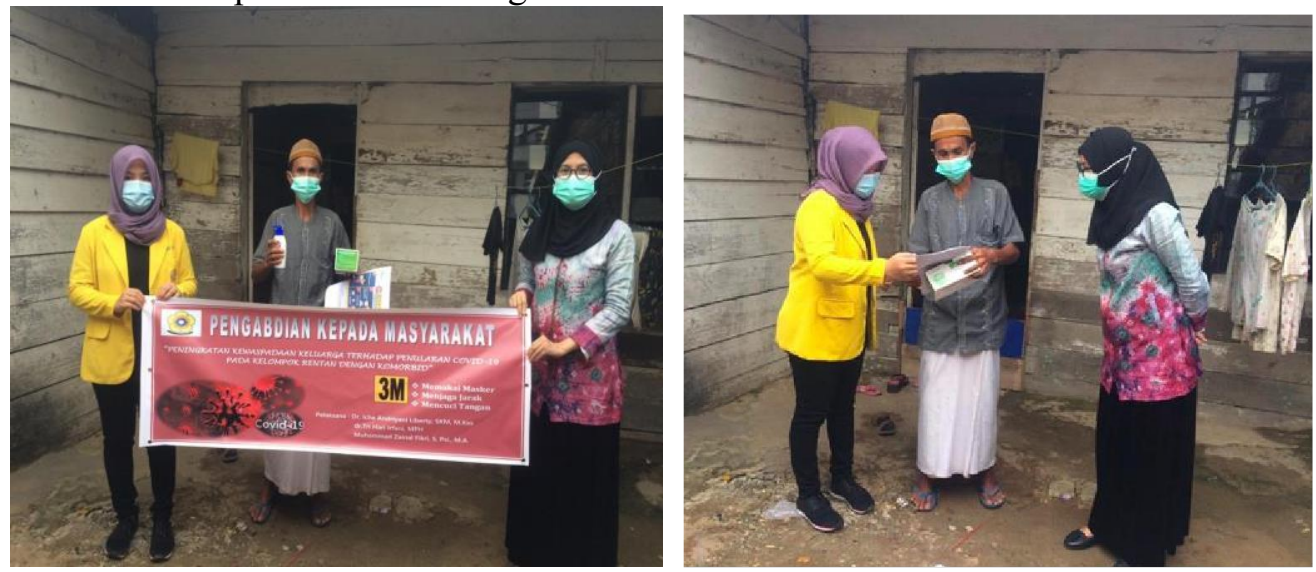

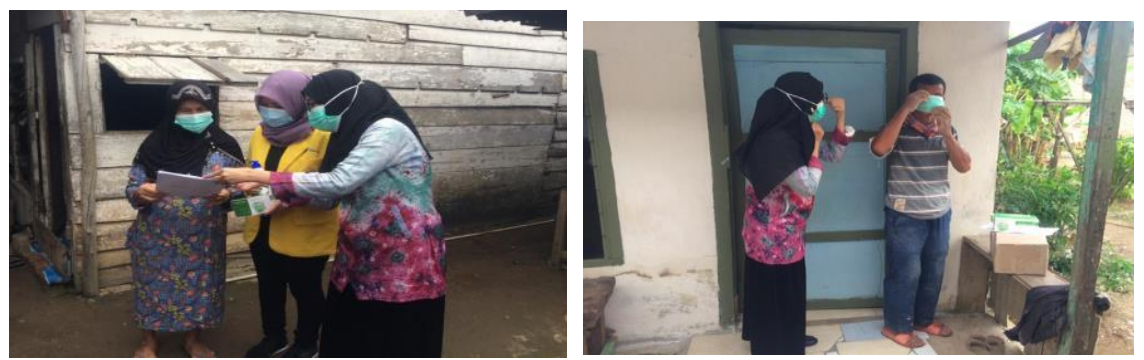

Fig 1. Conducting Home Visits to Provide Education on the Correct Implementation of Health Protocol Discipline

\section{CONCLUSION}

The conclusion that can be formulated is that based on interviews, questions and answers and observations during the activity, this community service activity resulted in an increase in knowledge about the importance of health protocols that were carried out in a disciplined and correct manner. This health protocol is carried out in order to protect each other starting from the family and for the community, especially for vulnerable communities. In addition to home visits, the construction of hand washing facilities will also be able to be used by the surrounding community and at the same time become a symbol to remind that washing hands with soap in running water is not only an obligation of the COVID-19 prevention health protocol but will also save many lives various other infectious diseases.

\section{ACKNOWLEDGMENTS}

The author would like to thank the Sriwijaya University Research and Community Service Institute (LPPM) which has provided financing for this activity with the activity contract number No.003/UN9/SK.LP2M.PM/2020 as well as students and the entire community who have participated in this community service activities.

\section{REFERENCES}

[1]. Van Bavel, Jay J., Aleksandra Cichocka, Valerio Capraro, Hallgeir Sjåstad, John B. Nezlek, Mark Alfano, Flavio Azevedo, et al., National Identity Predicts Public Health Support During a Global Pandemic: Results from 67 Nations, PsyArXiv. September 2. 2020, doi:10.31234/osf.io/ydt95.

[2]. World Health Organization. Global surveillance for COVID-19 disease caused by human infection with the 2019 novelcoronavirus. Geneva: World Health Organization; 2020.

[3]. World Health Organization. Infection prevention and controlduring health care when novel coronavirus (nCoV) infection issuspected. Geneva: World Health Organization; 2020.

[4]. World Health Organization. Critical preparedness, readiness and response actions for COVID-19. Geneva: World Health Organization; 2020.

[5]. World Health Organization. Coronavirus disease (COVID-19) advice for the public [Internet]. 2020 [Available from: https://www.who.int/emergencies/diseases/ novelcoronavirus-2019/advice-for-public. 
[6]. Pragholapati, A. 'New Normal "Indonesia" After COVID-19 Pandemic'. PsyArXiv, 2020.

[7]. Ramadhani, Y. (2020, June 4). Update Corona Hari Ini: 127 Jurnalis Dunia Meninggal oleh COVID-19. Retrieved June 17, 2020, from tirto.id: https://tirto.id/update-coronahari-ini-127-jurnalis-dunia-meninggal-olehcovid-19-fE5u

[8]. Kementrian Kesehatan RI. Coronavirus Desease (COVID-19), Dashboard. Online: https://infeksiemerging.kemkes.go.id/dashboard/covid-19, 2020.

[9]. Dinkes Sumsel. 2020. Situasi Terkini Perkembangan Corona Virus Disease-19 (COVID19) Provinsi Sumatera Selatan. Online: http://dinkes.sumselprov.go.id/, 2020.

[10]. Google Mobility Report. https://www.google.com/covid19/mobility/, 2020.

[11]. Wang, Guihua, Stay at Home to Stay Safe: Effectiveness of Stay-at-Home Orders in Containing the COVID-19 Pandemic (September 18, 2020). Available at SSRN: https://ssrn.com/abstract=3581873, 2020. 